\title{
BADANIA PROWADZONE W ZAKŁADZIE HISTORII HISTORIOGRAFII 1 METODOLOGII HISTORII INSTYTUTU HISTORII UNIWERSYTETU RZESZOWSKIEGO (2001-2016)
}

\section{ABSTRACT}

\section{RESEARCH CARRIED OUT AT THE DEPARTMENT OF HISTORY OF HISTORIOGRAPHY}

AND METHODOLOGY OF HISTORY OF THE INSTITUTE OF HISTORY AT THE UNIVERSITY

\section{OF RZESZOW (2001-2016)}

The systematic research in the field of the history of historiography at the University of Rzeszow ought to be connected with the establishment of the Department of History of Historiography and Methodology of History at the Institute of History in 1993. The cooperation with scientific circles from Poland, Austria, Germany and Ukraine led to the production and publication of a number of papers on the historical community of Lviv (until 1939) as well as theoretical studies on the history of historiography and biography. Owing to the rich ethnic and cultural mosaic, the former capital of Galicia created a unique opportunity to develop methodological concepts that introduced new fields of analysis and interpretation of sources. In the undertaken studies, we managed to combine a traditional, elitist and personalistic way of looking at a historical environment in cultural contexts, including areas where historiography the history of culture meet, and so do thehistory of education, the methodology of history, and the history of institutions, archives, libraries and scientific societies. The aim at that time was to focus on the problems of Polish and Ukrainian historiographies that created nations, the teaching and popularization of history, national heroes, and the role played by historians in the socio-political life of the Polish and Ukrainian nations. Particular attention was drawn to the processes of forming the history of historiography and methodology of history as separate historical subdisciplines, and Ukrainian scientific achievements in these fields were analyzed and the trends of their further development were pointed out. It was considered important to emphasize the role of methodological reflection for contemporary historiographic studies, as well as to identify the place that the methodology of history and history of historiography occupy in university education.

\section{KEYWORDS:}


Prowadzenie systematycznych badań z zakresu historii historiografii na Uniwersytecie Rzeszowskim należy wiązać z utworzeniem w 1993 r. w Instytucie Historii (wówczas Wyższej Szkoły Pedagogicznej) Zakładu Historii Historiografii i Metodologii Historii, kierowanego przez prof. dr hab. Jerzego Maternickiego'. Powołanie w 2001 r. Uniwersytetu Rzeszowskiego, stworzyło nowe podstawy finansowania nauki, wpłynęło korzystnie na dalszy rozwój i umiędzynarodowienie badań historiograficznych. Już w 2002 r. z inicjatywy J. Maternickiego zrodził się pomysł kontynuacji, zapoczątkowanych w latach 70. XX w., badań nad środowiskami historycznymi ${ }^{2}$ i objęcia nimi Lwowa, miasta o szczególnym znaczeniu dla kultury polskiej, ukraińskiej, ormiańskiej, niemieckiej i żydowskiej. Ze względu na bogatą mozaikę etniczną i kulturową, dawna stolica Galicji stwarzała niepowtarzalną szansę wypracowania koncepcji metodologicznych wytyczających nowe pola analizy i interpretacji źródeł. W zainicjowanych badaniach udało się połączyć tradycyjny, elitarno-personalistyczny sposób patrzenia na środowiska historyczne z ujęciem kulturologicznym, uwzględniającym obszary na styku historiografii i historii kultury, historii edukacji, metodologii historii, historii instytucji, archiwów, bibliotek i towarzystw naukowych. Powołany w 2002 r. i prowadzący prace do 2007 r., Międzynarodowy Zespół Badawczy „Wielokulturowe środowisko historyczne Lwowa w XIX i XX wieku”, kierowany przez J. Maternickiego, skupił blisko sześćdziesięciu badaczy z Polski, Ukrainy i Niemiec. W ten sposób udało się stworzyć pomost dla badań opartych na różnych tradycjach naukowych, wypracować podstawy wspólnych ocen lwowskich środowisk historycznych widzianych w perspektywie historiografii polskiej i ukraińskiej. W ramach realizowanego projektu wydano pięć tomów prac zespołowych poświęconych lwowskiej historiografii. ${ }^{3}$ Zaprezentowano w nich ustalenia i rozprawy badaczy z takich ośrodków akademickich jak Bielefeld,

\footnotetext{
1 Po odejściu prof. J. Maternickiego na emeryturę w 2012 r, pracami Zakładu HHiMH kierował dr hab. prof. UR Paweł Sierżęga (2012- 2014). Obecnie kierownikiem ZHHiMH IH UR jest dr hab. prof. UR Joanna Pisulińska.

2 Zob. J. Maternicki, Warszawskie środowisko historyczne 1832-1869, Warszawa 1970; Środowiska historyczne II Rzeczypospolitej. Materialy konferencji naukowych $w$ Krakowie i Lublinie 1984 i 1985, red. J. Maternicki, Warszawa 1986; Środowiska historyczne II Rzeczypospolitej, cz. II: Materialy konferencji naukowych w Cedzynie i Bialymstoku w 1986 i 1987, red. J. Maternicki, Warszawa 1987; Środowiska historyczne II Rzeczypospolitej, cz. III: Materiaty konferencji naukowych w Krakowie w 1988, red. J. Maternicki, Warszawa 1989; Środowiska historyczne II Rzeczypospolitej, cz. IV: Materialy konferencji naukowych w Krynicy w 1989 r., red. J. Maternicki, Warszawa 1990; Środowiska historyczne II Rzeczypospolitej, cz. V, red. J. Maternicki, Warszawa 1990; Warszawskie środowisko historyczne w okresie II Rzeczypospolitej, Rzeszów 1999.

3 Wielokulturowe środowisko historyczne Lwowa w XIX i XX wieku, t. I, pod red. J. Maternickiego, Rzeszów 2004; Wielokulturowe środowisko historyczne Lwowa w XIX i XX wieku, t. II, pod red. J. Maternickiego, L. Zaszkilniaka, Rzeszów 2004; Багатокультурне історичне середовище Аьвова в XIX і XX століттях. Wielokulturowe środowisko historyczne Lwowa w XIX i XX wieku, T. IV, pod red. J. Maternickiego i L. Zaszkilniaka, Lwów-Rzeszów 2006; Wielokulturowe środowisko historyczne Lwowa w XIX i XX wieku. T. V, pod red. J. Maternickiego i L. Zaszkilniaka, Rzeszów 2007.
} 
Drohobycz, Gdańsk, Iwano-Frankowsk, Katowice, Kielce, Kraków, Lublin, Lwów, Łódź, Poznań, Rzeszów, Toruń, Warszawa i Wrocław.

Istotnym uzupełnieniem i wzbogaceniem projektu było wydanie Złotej księgi historiografii lwowskiej XIX i XX wieku (Rzeszów 2007). Jej koncepcja została opracowana przez J. Maternickiego, a tom zredagowany przy wspólpracy prof. Leonida Zaszkilniaka z Narodowego Uniwersytetu Lwowskiego im. Iwana Franki. Do udziału w projektowanym wydawnictwie zaproszeni zostali historycy historiografii i dziedzin pokrewnych z dziesięciu ośrodków akademickich polskich i ukraińskich. Opracowano sylwetki naukowe trzydziestu sześciu badaczy lwowskich, reprezentujących różne dziedziny nauk humanistycznych, przede wszystkim historię. Przez pryzmat jednostek scharakteryzowano dorobek naukowy lwowskiej humanistyki, ukazując Lwów jako ważny ośrodek badań historycznych w Europie Środkowowschodniej. W zaprezentowanych biogramach autorzy akcentowali dorobek naukowy historyków, ich poglądy i postawy metodologiczne, działalność naukowo-organizacyjną, osiągnięcia dydaktyczne oraz wpływ na kształtowanie kultury i świadomości historycznej społeczeństwa polskiego i ukraińskiego. W ten sposób udało się wypełnić dotkliwą lukę w opracowaniach biograficznych poświęconych lwowskiemu cechowi historyków.

Kontynuacją polsko-ukraińskiej współpracy było powołanie w Rzeszowie w 2006 r. kolejnego, blisko czterdziestoosobowego Międzynarodowego Zespołu Badawczego „Historia-mentalność-tożsamość. Miejsce i rola historii oraz historyków w życiu narodu polskiego i ukraińskiego w XIX i XX wieku". Jego pracami kierowali J. Maternicki i L. Zaszkilniak. W skład ścisłego komitetu wchodzili: prof. prof. Włodzimierz Bonusiak z Uniwersytetu Rzeszowskiego, Rafał Stobiecki z Uniwersytetu Łódzkiego, Andrzej Stępnik z UMCS w Lublinie, Witalij Telwak z Uniwersytetu w Drohobyczu, Wojciech Wrzosek z Uniwersytetu Adama Mickiewicza w Poznaniu. Sekretarzami, podobnie jak w przypadku prac poprzedniego zespołu, zostali dr. dr. Joanna Pisulińska i Paweł Sierżęga z Uniwersytetu Rzeszowskiego. W przyjętym programie badań skoncentrowano się na problemach narodotwórczej roli historiografii polskiej i ukraińskiej, nauczaniu i popularyzacji dziejów, bohaterach narodowych w świadomości historycznej Polaków i Ukraińców, polskich i ukraińskich mitach historycznych, ideologiach historycznych w polskich i ukraińskich partiach politycznych oraz roli jaką odegrali historycy w życiu społeczno-politycznym narodów polskiego i ukraińskiego. 
Pierwsza z cyklu konferencji „Historia-mentalność-tożsamość” została zorganizowana w Rzeszowie w 2007 r. ${ }^{4}$ Kolejne w Poznaniu, Łodzi, Lwowie i Gdańsku.

Ze względu na niesłabnące zainteresowanie historyków podejmowaniem wspólnych badań, w Rzeszowie zrodził się pomysł $1^{6}$, aby nadać im formę instytucjonalną. Po dwuletnim okresie przygotowań, na zorganizowanej w Gdańsku konferencji, 23 września 2011 r., zostało zawiązane Towarzystwo Historiograficzne z siedzibą w Rzeszowie. Jego pierwszym prezesem został Jerzy Maternicki ${ }^{7}$. Zgodnie z przyjętym Statutem, celem TH jest „organizacja i wspieranie badań w zakresie historii historiografii, metodologii historii, teorii wiedzy i kultury historycznej, dziejów edukacji historycznej oraz upowszechnianie ich wyników w społeczeństwie”. Obecnie do TH należy blisko sto osób z Polski, Austrii, Białorusi, Rosji i Ukrainy. W ramach prac Towarzystwa w 2012 r. zorganizowano w Rzeszowie seminarium naukowe poświęcone biografistyce w kontekście badań historiograficznych - „Monografie historyków: oczekiwania i rzeczywistość". Głównym tematem spotkania było krytyczne omówienie pojawiających się w Polsce i na Ukrainie prac poświęconych historykom oraz dyskusja nad oczekiwanym kształtem metodologicznym tego typu publikacji. Podjęto też refleksję nad przemianami zachodzącymi w polskiej i ukraińskiej humanistyce oraz ich wpływem na badania w zakresie historii historiografii. Ze względu na ożywioną dyskusję, w kolejnym, 2013 r., w rzeszowskim środowisku historyków historiografii zdecydowano o organizacji konferencji naukowej „Historia historiografii i metodologia historii w Polsce i na Ukrainie - tradycje i współczesność”. W jej trakcie zwrócono uwagę na procesy formowania się historii historiografii i metodologii historii jako

4 Efektem prac Zespołu jest opracowanie Historia-mentalność tożsamość. Miejsce i rola historii oraz historyków w życiu narodu polskiego i ukraińskiego w XIX i XX wieku, pod red. J. Pisulińskiej, Pawła Sierżęgi, L. Zaszkilniaka, opatrzone wstępem J. Maternickiego, Rzeszów 2008.

5 Rezultatem przeprowadzonych spotkań są publikacje: Historia-mentalność-tożsamość. Studia z historii, historii historiografii i metodologii historii, pod red. K. Polasik-Wrzosek, W. Wrzoska i L. Zaszkilniaka, Poznań 2010; Mity i stereotypy w dziejach Polski i Ukrainy w XIX i XX wieku, pod red. A. Czyżewskiego, R. Stobieckiego, T. Toborka, L. Zaszkilniaka, Warszawa-Łódź 2012; Історія-ментальність-ідентичність. Історична пам' ять українців і паляків y період формування національної свідомості в XIX - першій половині XX столітmя (Historia-mentalność-tożsamość. Pamięć historyczna Ukraińców i Polaków w okresie kształtowania się ich świadomości narodowej (wiek XIX i pierwsza połowa XX), t. IV, Lwów 2011; Historia-mentalność-tożsamość. Rosja i Europa Zachodnia w polskiej i ukraińskiej historiografii XIX i XX wieku, red. E. Koko, M. Nowak, L. Zaszkilniak, Gdańsk 2013.

6 Pomysłodawczynią była dr hab. prof. UR Mariola Hoszowska, wówczas kierownik Zakładu Dydaktyki Historii.

7 Obecnie pracami Towarzystwa Historiograficznego kieruje dr hab. prof. UR Paweł Sierżęga. W skład Zarządu Głównego TH wchodzą: dr hab. prof. UG Barbara Klassa (Gdańsk) - wiceprezes; dr hab. prof. UŁ Jolanta Kolbuszewska (Łódź) - wiceprezes; prof. dr hab. Andrzej Wierzbicki (Warszawa) - wiceprezes; prof. dr hab. Leonid Zaszkilniak (Lwów) - wiceprezes; dr hab. prof. UR Joanna Pisulińska (Rzeszów) - sekretarz; dr Agnieszka Kawalec (Rzeszów) - skarbnik; dr hab. prof. UW Katarzyna Błachowska (Warszawa) - członek; dr hab. prof. UR Mariola Hoszowska (Rzeszów) - członek; dr hab. prof. UAM Violetta Julkowska (Poznań) - członek; prof. dr hab. Jan Pomorski (Lublin) - członek; dr Ewa Solska (Lublin) - członek; prof. dr hab. Rafał Stobiecki(Łódź) - członek; prof. dr hab. Witalij Telwak (Drohobycz) - członek; prof. dr hab. Wojciech Wrzosek (Poznań) - członek. 
odrębnych subdyscyplin historycznych, dokonano bilansu polskiego i ukraińskiego dorobku naukowego w tych dziedzinach oraz wskazano na trendy ich dalszego rozwoju. Za istotne uznano podkreślanie roli refleksji metodologicznej dla współczesnych badań historiograficznych, a także określenie miejsca, jakie metodologia historii i historia historiografii zajmują w dydaktyce uniwersyteckiej ${ }^{8}$.

Ugruntowaniem badań prowadzonych w ZHHiMH IH UR nad lwowskim środowiskiem historycznym, była realizacja projektu w ramach Narodowego Programu Rozwoju Humanistyki „Wspólne dziedzictwo. Historiografia polska i ukraińska w XIX i XX wieku (do 1939 r.), kierowanego przez dr hab. prof. UR Mariolę Hoszowską. W realizacji trzyletniego grantu (lata 2013-2016) wzięło w nim udział ponad trzydzieści osób reprezentujących ośrodki akademickie w Rzeszowie, Lwowie, Drohobyczu, Iwano-Frankowsku, Poznaniu, Warszawie, Kielcach, Łodzi, Lublinie, Gdańsku, Katowicach i Wiedniu. Pierwszą z prac wydaną w ramach grantu była monografia Marioli Hoszowskiej Szymon Askenazy i jego korespondencja z Ludwikiem Finklem (Rzeszów 2013). Wydawnictwo źródeł, obejmujące listy z lat 1897-1926, zostało poprzedzone gruntownym opracowaniem autorki, skoncentrowanym na życiu prywatnym i działalności naukowej jednego z najwybitniejszych przedstawicieli polskiego neoromantyzmu. Kolejną publikacją opartą na szeroko zakrojonych badaniach archiwalnych, był drugi tom Złotej księgi historiografii lwowskiej XIX i XX wieku (Rzeszów 2014), przygotowany pod red. J. Maternickiego, P. Sierżęgi i L. Zaszkilniaka. Znalazły się w nim biografie nie tylko czołowych przedstawicieli lwowskiej Klio, ale też historyków dalszego planu, choć o znaczącym dorobku naukowym i organizacyjnym. Duże zainteresowanie obu publikacjami pozwala sądzić, że w przyszłości prawdopodobnie uda się podjąć prace nad tomem trzecim, który podobnie jak dwa poprzednie wzbogaci naszą wiedzę o Lwowie jako ośrodku badań historycznych. W tym samym 2014 roku, została we Lwowie zorganizowana konferencja naukowa poświęcona dopracowaniu i uściśleniu zagadnień wchodzących w zakres planowanej syntezy studium historycznego na Uniwersytecie Lwowskim (do 1939 r.). Wzięło w niej udział blisko czterdzieści osób z Polski i Ukrainy. Na spotkaniu tym przedyskutowano ostateczny ksztalt przyszłego wydawnictwa oraz prezentowano cząstkowe wyniki prowadzonych kwerend ${ }^{9}$. Pracą o fundamentalnym znaczeniu dla studiów nad funkcjonowaniem historii w lwowskiej Alma Mater, jest opracowana w ramach grantu Historia w Uniwersytecie Lwowskim. Badania i nauczanie do 1939 r., pod red. J. Maternickiego, J. Pisulińskiej i L. Zaszkil-

8 Pokłosiem konferencji jest praca Historia historiografii i metodologia historii w Polsce i na Ukrainie (Icmopis історіографіі і методологіл історіі в Польщзі та в Україні), pod red. J. Maternickiego, J. Pisulińskiej i L. Zaszkilniaka, Rzeszów 2015.

9 Rezultatem obrad jest praca Iсторіл mа історики у Аввівському університеті: традиції та сучасність

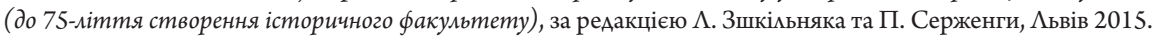


niaka (Rzeszów 2016). Jest to pierwsza na rynku polskim monografia, która w sposób gruntowny i syntetyczny przedstawia regulacje prawne dotyczące organizacji studiów historycznych na Wydziale Filozoficznym/Humanistycznym w latach 1869-1939, organizację i obsadę personalną katedr, charakterystykę kadry nauczającej, ofertę programową oraz działalność naukową i dydaktyczną profesorów. Dzieje historii na Uniwersytecie Lwowskim zostały przedstawione w kontekście przemian ideowych, politycznych i oświatowych zachodzących w Galicji do chwili odzyskania niepodległości, i podobnie w okresie II Rzeczypospolitej. Lwowskie badania udało się pokazać na tle dorobku historycznego innych uniwersytetów, wskazując na ich specyfikę i przybliżając wartość w dorobku polskiej i ukraińskiej humanistyki.

Zakres prac prowadzonych w Zakładzie Historii Historiografii IH UR, zdecydowat, że w 2014 r. jego pracownicy zostali zaproszeni do przygotowania panelu „Mediewistka lwowska w XIX i XX w. (do 1939 r.), w ramach odbywającego się w Rzeszowie, w dniach 20- 24 września 2015 r., V Kongresu Mediewistów Polskich, poświęconego kontaktom międzykulturowym w średniowieczu, któremu przewodniczył prof. Leszek P. Słupecki (UR). Obrady sekcji w ramach jednego z najważniejszych spotkań badaczy średniowiecza, zostały objęte patronatem Towarzystwa Historiograficznego i poświęcone analizie poglądów metodologicznych i warsztatowych historyków lwowskich: polskich i ukraińskich, ich zainteresowaniom badawczym, dokonaniom twórczym, a także organizacji i ofercie programowej studiów w zakresie średniowiecza i nauk pomocniczych historiii"

W 2009 roku z inicjatywy prof. J. Maternickiego i dr Tomasza Szuberta z Wiednia w ZHHiMH IH, rozpoczęto przygotowania do realizacji kolejnego projektu „Galicja 1772- 1918”. Jego zamierzeniem było ożywienie badań nad dziejami ziem polskich, anektowanych w wyniku rozbiorów przez Habsburgów. Szczególny nacisk położono na wzajemne relacje zamieszkujących Galicję narodów i grup etnicznych, stosunki polityczne łączące prowincję z Wiedniem, przemiany polityczne, społeczne i gospodarcze, działalność samorządów, rozwój oświaty, nauki, literatury, sztuki, prasy, a także życie codzienne. W skład Prezydium Zespołu wchodzili: Jerzy Maternicki (przewodniczący i kierownik projektu) oraz wiceprzewodniczący: prof. prof. Waldemar Łazuga (Uniwersytet im. Adama Mickiewicza w Poznaniu), Wacław Wierzbieniec (Uniwersytet Rzeszowski), Leonid Zaszkilniak (Uniwersytet im. Iwana Franki we Lwowie). Sekretarzami Zespołu zostali Agnieszka Kawalec (Uniwersytet Rzeszowski), Tomasz Szubert (Verein für die Geschichte Galiziens, Wiedeń) oraz Damian Szymczak (Uniwersytet im. Adama Mickiewicza w Poznaniu). W projekcie wzięli udział przedstawiciele nauk humanistycznych z Polski, Ukrainy, Austrii, Słowacji i Węgier.

10 Materiały z obrad sekcji zostały złożone do druku w 2015 r. Obradom sekcji historiograficznej patronował J. Maternicki, moderował P. Sierżęga. 
Jednym z pierwszych zrealizowanych zadań była organizacja międzynarodowej konferencji „Historia Galicji 1772- 1918 - problemy metodologiczne, stan i potrzeby badań" (Czudec 18- 19 listopada 2010 r.). Efektem tego spotkania jest trzytomowe opracowanie obejmujące ponad siedemdziesiąt rozpraw, pod redakcją A. Kawalec, W. Wierzbieńca i L. Zaszkilniaka. ${ }^{11} \mathrm{~W}$ kolejnych latach zostały zorganizowane konferencje w Poznaniu, Przemyślu, Lwowie i ponownie w Rzeszowie, poświęcone infrastrukturze, polityce i pamięci historycznej, organizacji i kulturze podróżowania, roli Galicji w powstaniu styczniowym oraz warunkom życia kobiet w zaborze austriackim ${ }^{12}$. Ze względów finansowych nie udało się zrealizować wszystkich zamierzeń zespołu. Zawieszono prace nad syntezą i encyklopedią Galicji. Udało się natomiast powołać do życia rocznik o charakterze interdyscyplinarnym „Galicja. Studia i materiaty”. Pierwszy tom pisma ukazał się w 2015 r., kolejny, drugi został wydany w 2016 r. i dedykowany filozofii w Galicji1 ${ }^{13}$. W 2017 roku ukaże się rocznik obejmujący prace poświęcone Zakładowi Narodowemu im. Ossolińskich oraz roli mecenatu społecznego w XIX w. Integralną częścią pisma są Materialy do bibliografii Galicji, opracowywane za kolejne lata, począwszy od $2010 \mathrm{r}$.

Udział we wspomnianych wyżej programach badawczych, stał się dla wielu rzeszowskich historyków, inspiracją do podejmowania indywidualnych studiów poświęconych lwowskiemu środowisku historycznemu. Istotne w tym zakresie są monografie Jerzego Maternickiego: Historia i historycy. Studia i szkice historiograficzne (Rzeszów 2005), Historia i życie narodu. Poglady i postawy historyków polskich XIX iXX w. (Rzeszów 2009), Walerian Kalinka (1826-1886) i jego badania nad epoka porozbiorowa (Rzeszów 2013) oraz Ztote lata historiografii polskiej we Lwowie (Rzeszów 2015); Joanny Pisulińskiej Lwowskie środowisko historyczne w okresie międzywojennym (1918- 1939) (Rzeszów 2012); Pawła Sierżęgi, Kazimierz Tyszkowski (1894- 1940). Z dziejów nauki polskiej w międzywojennym Lwowie (Rzeszów 2011); Agnieszki Kawalec Ksiądz Franciszek Siarczyński. Życie i działalność (Wrocław 2007); Marioli Hoszowskiej

11 Galicja 1772- 1918. Problemy metodologiczne, stan i potrzeby badań, t. I, II, III, pod red. A. Kawalec, W. Werzbieniec, L. Zaszkilniak, wstępem opatrzył J. Maternicki, Rzeszów 2011.

12 Opublikowano: Galicja a powstanie styczniowe, pod red. M. Hoszowskiej, A. Kawalec, L. Zaszkilniak, Rzeszów 2013; Galicyjskie drogi i bezdroża. Studium infrastruktury, organizacji i kultury podróżowania, t. I., red. J. Kamińska-Kwak, Rzeszów 2013, t. II, red. Z. Budzyński, J. Kamińska-Kwak, Przemyśl-Rzeszów 2016; Życie codzienne, gospodarka, kultura i spoleczeństwo polskie w latach 1772-1918. Rozprawy z dziejów ziem polskich w okresie zaborów, pod red. W. Łazugi i D. Szymczaka, Poznań 2015; Między polityka, historią a pamięcią historyczną. Studia z dziejów Polski okresu porozbiorowego, red. W. Łazuga i S. Paczos, Poznań 2015; Galicja i jej dziedzictwo, t. 22. Szkolnictwo i oświata $w$ Galicji 1772- 1918, red. J. Dybiec, J. Krawczyk, A. Meissner, K. Szmyd, Rzeszów 2015; Galicja i jej dziedzictwo, t. 24. Kobieta w Galicji. Nowoczesność i tradycja, pod red. J. Kamińska-Kwak, S. Kozak, D. Opaliński, Rzeszów 2016.

13 Rocznik jest wydawany w formie tradycyjnej i internetowej. W skład redakcji wchodzą: S. Kozak (red. naczelny), A. Kawalec (z-ca redaktora), P. Sierżęga (sekretarz), J. Kuzicki (członek). Pismo dostępne jest pod adresem: www.galicja.ur.edu.pl/ 
Ludwik Finkel i Akademia Umiejętności. Z dziejów wspótpracy naukowej Lwowa i Krakowa na przełomie XIX i XX wieku (Rzeszów 2011). W rzeszowskim środowisku historyków podejmowane są też badania $\mathrm{z}$ historii historiografii uwzględniające rozważania o kulturze historycznej, myśli historycznej, dydaktyce i edukacji historycznej. Niejednokrotnie stanowiły one podstawę uzyskanych doktoratów i habilitacji. Tytułem przykładu należy wymienić autorstwa Joanny Pisulińskiej Żydzi w polskiej myśli historycznej doby porozbiorowej (1795-1914) (Rzeszów 2004); Elżbiety Cesarz Chłopi w polskiej myśli historycznej doby porozbiorowej 1795-1864. Syntezy, parasyntezy i podręczniki dziejów ojczystych (Rzeszów 1999), Marioli Hoszowskiej Siła tradycji, presja życia. Kobiety w podręcznikach dziejów Polski (1795-1918) (Rzeszów 2005). Należy też wspomnieć o wydanym pod red. Jerzego Maternickiego kompendium Wspótczesna dydaktyka historii. Zarys encyklopedyczny (Warszawa 2004) oraz opracowaniu poświęconemu mitologizacji historii i metodologicznym aspektom badań historycznych Pogranicza historii. Studia i szkice (Rzeszów 2011). Na osobną uwagę zasługuje wcześniejsza praca Metodologiczne problemy syntezy historiografii polskiej (1998), która ukazała się pod red. J. Maternickiego, a powstała w wyniku zorganizowanej w Rzeszowie dwa lata wcześniej konferencji i dyskusji nad kształtem, założeniami metodologicznymi i wydawniczymi planowanego wydawnictwa ${ }^{14}$. Pomimo, że dotąd nie doczekaliśmy się syntetycznego ujęcia dziejów historiografii polskiej, konferencja zainicjowała badania cząstkowe w tym zakresie.

Warto wspomnieć, że w Zakładzie Historii Historiografii i Metodologii Historii IH UR systematycznie prowadzone jest seminarium naukowe, gromadzące także pracowników Zakładu Edukacji i Kultury Historycznej, Zakładu Historii XIX wieku oraz doktorantów i magistrów.

W ubiegłym roku prof. Jerzy Maternicki obchodził osiemdziesiąte urodziny. Środowiska naukowe w Polsce, na Ukrainie i w Austrii, w uznaniu dorobku naukowego i prowadzonej działalności organizacyjnej na rzecz rozwoju badań historiograficznych i dydaktycznych w Polsce, ofiarowały Jubilatowi zbiór studiów Historia. Ciaggłość i zmiana. Studia ofiarowane Profesorowi Jerzemu Maternickiemu, pod red. M. Hoszowskiej, J. Pisulińskiej i P. Sierżęgi (Rzeszów 2016).

Podsumowując, w okresie od powstania ZHHiMH w IH UR, badania z historii historiografii, kultury i edukacji historycznej prowadzi systematycznie sześć osób. Wydano z tego zakresu ponad dwadzieścia monografii indywidualnych i zbiorowych prac pod redakcją. Stanowią one istotny wkład rzeszowskich i lwowskich historyków

14 W obradach wzięli udział Jerzy Maternicki, Andrzej Feliks Grabski, Jerzy Topolski, Wojciech Wrzosek, Andrzej Radomski, Stefan Bielański, Jan Pomorski, Antoni Krawczyk, Andrzej Wierzbicki, Krzysztof Zamorski. Rafał Stobiecki, Zbigniew Romek, Krzysztof Maciej Kowalski. 
w rozwój badań historycznych w Polsce i na Ukrainie. W ciągu blisko dwudziestu lat działalności Zakładu HHiMH kierowanego przez Jerzego Maternickiego udało się zintegrować wokół wspólnych projektów niemal wszystkie środowiska historiograficzne w Polsce, a także sporą cześć czołowych badaczy z Ukrainy, a także z Niemiec i Austrii. Tworzenie platformy pod wspólne, interdyscyplinarne badania, wyznacza normę dla podejmowania dalszych w tym względzie prac. W roku 2017, w Rzeszowie zostanie zorganizowana konferencja naukowa „Wspólne dziedzictwo. Rzeczypospolita Obojga Narodów w polskiej i ukraińskiej myśli historycznej XIX i XX w.. Planowane są kolejne monografie pracowników poświęcone m.in. Teofilowi Emilowi Madelskiemu, Augustowi Bielowskiemu, Stanisławowi Zakrzewskiemu i Wiktorowi Czermakowi. 